\title{
Huawei ./. ZTE, or, how the CJEU closed the Orange Book
}

\author{
Philipp Maume \\ Assistant Professorship Corporate Governance and Capital Markets Law, Technical University of Munich
}

The interface between intellectual property law and competition law is complicated. The interaction between prohibited abuse of market power under EU competition law and national intellectual property rights has been a perennial issue for courts on both the $E U$ and the member-state level. The issue became even more complicated by the ongoing standardization movement which raised concerns about the anticompetitive nature of standardization agreements and possible implications for compulsory licensing. The practical question was the availability of injunctive relief for infringements of patents that are essential to an established market standard. In July 2015, the Court of Justice of the European Union put an end to the simmering conflict between the European Commission and German patent litigation courts. The new ruling Huawei .I.ZTE is ground breaking and transcends the borders of competition law, partially harmonizing patent litigation practice in Europe.

Keywords: abuse of market power, Huawei ./. ZTE, standardization, FRAND, Orange Book Standard, essential facilities doctrine, IMS Health

\section{INTRODUCTION}

The interaction of intellectual property (IP) law and competition law is a complicated issue. Both areas seek to promote innovation, but apply different approaches. While competition law tries to address the dangers presented by market power and anticompetitive conduct, IP laws promote innovation by limiting competition. This tension resulted in two famous European Court of Justice (ECJ) decisions. In Magill (1995) and IMS Health (2004), the ECJ held that while the exercise of an IP right does not constitute an abuse of market power in general, the exercise can be abusive in exceptional circumstances. The consequence would be the obligation to grant a licence on fair, reasonable and non-discriminatory terms.

In 2013 the District Court Düsseldorf applied to the Court of Justice of the European Union (CJEU) ${ }^{1}$ for a preliminary ruling on the interpretation of Art 102 of the Treaty on the Functioning of the European Union (TFEU) in relation to standard-essential patents. The application was triggered by opposing approaches taken by the German Federal Court of Justice in the landmark decision Orange Book Standard in 2009, and by the European Commission in the investigations against Samsung and Motorola in 2012. On 16 July 2015 the CJEU published its longanticipated decision Huawei ./. ZTE. The court held that the enforcement of an essential patent is an exceptional circumstance which could constitute an abuse of market power. In particular, applying for an injunction order in respect of such a patent

1. Under the Treaty of Lisbon (2009), the European Court of Justice was renamed Court of Justice of the European Union. 
could constitute a breach of Art 102 TFEU. The court also prescribed a negotiation procedure which would allow the proprietor to keep the door open for an injunction order if the user delayed licence negotiations.

Following this chronology, this article discusses in section 2 the legal background for competition-law-based compulsory licensing in Europe. Section 3 will outline the developments in Germany, focusing on the Orange Book Standard decision. Section 4 will consider the particularities of standardization agreements and FRAND declarations, which form the background of the European Commission's approach. Section 5 will analyse the decision Huawei ./. ZTE. The article concludes with a short summary and outlook.

\section{COMPULSORY LICENSING IN EUROPE}

\subsection{Abuse of market power, tying and essential facilities}

Art 102 TFEU protects competition by addressing market structures which are potentially harmful for competition. In contrast to its US counterpart (Sec 2 of the Sherman Antitrust Act), EU law does not prohibit market dominance and monopolization as such, but only its abuse. ${ }^{2}$ In simple terms, a dominant undertaking is prohibited from conduct which would be considered appropriate for 'regular' undertakings. Examples of such prohibited conduct are listed in Art 102(2) TFEU. Most relevant for the abuse of intellectual property rights are the doctrines of leveraging and essential facilities.

A dominant undertaking abuses its market power by leveraging if it transfers its power in one specific market into a separate market. This could be achieved by tying, which means making a contract subject to supplementary conditions which have no connection with the subject of the contract. An example is the sale of nail guns by a dominant undertaking in combination with consumables designed for them, namely cartridge strips and nails. ${ }^{3}$ Nail guns and the respective consumables are two distinct markets, and the undertaking's market share in respect of nail guns will most likely grow because of the leveraged market power in respect of compatible consumables. Arguably the most important ECJ case on leveraging is Commercial Solvents, in which a manufacturer of raw material (aminobutanol, which is required for manufacturing tuberculosis medication) was found to have abused a dominant position by refusing to continue to supply a downstream competitor. ${ }^{4}$

The leveraging doctrine reaches its limits when there is just one market, rather than two separate markets. This is the case when a company has a facility at its exclusive disposal which grants the company access to a particular market. The facility functions as a bottleneck, keeping competitors out of the market. For example, in an emblematic US case a consortium of railroad companies controlled all bridges into the railway

2. M Lamping, 'Refusal to Licence as an Abuse of Market Dominance: From Commercial Solvents to Microsoft', in KC Liu and R Hilty (eds), Compulsory Licensing: Practical Experiences and Ways Forward (Heidelberg/New York/Dordrecht/London, Springer, 2014) 121, 126; EM Fox, 'Monopolization and Dominance in the United States and the European Community: Efficiency, Opportunity and Fairness' (1986) 61 Notre Dame LR 981.

3. European Court of Justice, Judgment of 2 March 1994, Case C-53/92 P, Hilti v Commission.

4. European Court of Justice, Judgment of 6 March 1974, Joint Cases C-6/73 and C-7/73 Commercial Solvents. Another leading decision is European Court of Justice, Case C-311/84, 3 October 1985 - Télémarketing. 
station of St. Louis. ${ }^{5}$ As a result, competitors could not offer any services from or into the railway station. Under the Essential Facilities Doctrine (EFD) owners of such facilities can be under an obligation to grant their competitors access to the facility if the competitors are unable to duplicate it. ${ }^{6}$ As a result, the consortium would have to grant their competitors permission to use the respective bridges.

The EFD fell on fertile ground in Europe. The leading case ${ }^{7}$ is Bronner, ${ }^{8}$ in which an Austrian publishing company (Mediaprint) had created a home delivery scheme for newspapers. Oscar Bronner, another publisher, demanded access to this scheme in return for fair compensation. This was problematic because, as the Advocate General put it, 'the mere fact that by retaining a facility for its own use a dominant undertaking retains an advantage over a competitor cannot justify requiring access to it'. ${ }^{9}$ On the other hand, the home delivery system might deliver such an advantage that the market structure could develop towards an unwanted monopoly. The ECJ ruled in favour of Mediaprint, stating that the distribution network was not an essential facility because Bronner would - in principle - have been able to establish a delivery system himself.

\subsection{Market abuse and IP}

The question is how IP rights fit into this framework. The problem is that the basis of IP is exclusivity. Only the proprietor may use the protected technology or goods. The ECJ held in earlier decisions that despite their exclusionary nature, IP rights do not automatically confer a dominant market position. ${ }^{10}$ The exercise of rights conferred by intellectual property laws is not abusive, ${ }^{11}$ but can be abusive in exceptional circumstances. ${ }^{12}$ The remedy for such abusive conduct would be the obligation to grant a licence on fair, reasonable and non-discriminatory terms, enabling the competitor to use the protected technology or goods (so-called compulsory licence).

\subsubsection{Magill and IMS Health}

The first leading case on these 'exceptional circumstances' was Magill in $1995 .^{13}$ The Irish Magill TV Guide Ltd wanted to publish a weekly TV guide containing all TV

5. United States v Terminal Railroad Association, 224 U.S. 383 (1912).

6. For discussion of the EFD in general, see AB Lipsky Jr and JG Sidak, 'Essential Facilities' (1999) 51 Stanford LR 1187; B Frischmann and S Weber Waller, 'Revitalizing Essential Facilities' (2008) 75 Antitrust LJ 1; SJ Evrard, 'Essential Facilities in the European Union: Bronner and Beyond' (2003-2004) 10 Columbia J of Europ L 491.

7. Evrard, supra (n 6), 1 ('a catalyst').

8. European Court of Justice, Judgment of 26 November 1998, Case C-7/97 - Oscar Bronner v Mediaprint.

9. European Court of Justice, Opinion of Advocate General Jacobs, delivered on 28 May 1998, para 57. This opinion is still regarded as the theoretical foundation for refusal-to-deal situations under EU competition law.

10. European Court of Justice, Judgment of 29 February 1968, Case No 24/67 - Parke, David \& Co.; see also European Court of Justice, Judgment of 8 June 1971, Case No 78/70 - Deutsche Grammophon.

11. European Court of Justice, Judgment of 23 May 1978, Case No 102/77 - Hoffmann-La Roche $v$ Centrapharm.

12. European Court of Justice, Judgment of 5 October 1988, Case 238/87 - Volvo v Veng.

13. European Court of Justice, Judgment of 6 April 1995, Joined Cases C-241/91P and C-242/ $91 \mathrm{P}-$ Magill. 
programmes available in Ireland. The broadcasters refused to make the information available and argued that the programme information was subject to copyright protection in Ireland and in the UK. After decisions made by the Commission and the Court of First Instance (CFI, now the General Court), the ECJ confirmed that the circumstances in Magill were sufficiently exceptional because the information (the 'raw material') was indispensable for the production of a comprehensive TV guide. By refusing to grant the licence the broadcasters prevented the emergence of a new product. Moreover, referring to Commercial Solvents, in refusing to provide this essential information, the broadcasters would monopolize a downstream market.

The second major decision, IMS Health, was handed down in 2004. ${ }^{14}$ IMS Health Inc. had developed a database structure, separating the German market for pharmaceutical sales data into 1860 regions ('bricks'). This structure was protected under German copyright laws. IMS Health rejected a request from a competitor (NDC Health) to grant a licence for the use of this structure. NDC Health created new, unprotected structures with 2201 and 3000 bricks. However, the 1860 structure was so firmly entrenched in the German market that the customers refused to change to a new format, making the 1860 structure a de facto industry standard. The ECJ stated that in such a case the refusal to grant a licence would be abusive on three conditions. First, the refusal is able to eliminate all competition in the downstream market. Second, the undertaking demanding the licence must use the licence to offer new products or services not offered by the proprietor for which there is a potential consumer demand (new product test). Third, the refusal is not justified by objective considerations.

Magill and in particular IMS Health triggered a wave of comments and criticism. ${ }^{15}$ The topics can broadly be put into two interrelated categories. First, the court's reasoning in respect of the downstream market was seen as incoherent with previous decisions on abusive leveraging by some commentators. The distinction between upstream and downstream markets was seen as artificial because, strictly speaking, in the situation addressed by IMS Health no upstream market existed. ${ }^{16}$ However, it seems more convincing to understand the decision as a straight application of the

14. European Court of Justice, Judgment of 29 April 2004, Case C-418/01 - IMS Health v NDC Health.

15. See, for example, M Leistner, 'Intellectual Property and Competition Law: The European Development from Magill to IMS Health Compared to Recent German and US Case Law' (2005) Zeitschrift für Wettbewerbsrecht 138; A Heinemann, 'Compulsory Licences and Product Integration in European Competition Law - Assessment of the European Commission's Microsoft Decision' (2005) 36 IIC 63; SB Völcker, 'The Implications of Microsoft and IMS Health: Interesting Times for Dominant Intellectual Property Holders in Europe' (2004) 17 Competition Law Insight 14; B Sufrin, 'The IMS Case' (2004) 3 Competition LJ 18; SB Opi, 'The Application of the Essential Facilities Doctrine to Intellectual Property Licensing in the European Union and the United States: Are Intellectual Property Rights Still Sacrosanct?' (2000-2001) 11 Fordham Int Property, Media and Entertainment LJ 409; JT Lang, 'The Application of the Essential Facility Doctrine to Intellectual Property Rights under European Competition Law' in F Lévêque and H Shelanski (eds), Antitrust, Patents and Copyright (Edward Elgar, Cheltenham 2005) 56; R Coco, 'Antitrust Liability for Refusal to Licence Intellectual Property: A Comparative Analysis and the International Setting' (2008) 12 Marquette Int Prop LR 3; H Hovenkamp, MD Janis and MA Lemley, 'Unilateral Refusals to Licence' (2006) 2 J Comp L \& Econ 1.

16. Lamping, supra (n 2), 133. B Conde-Gallego, 'Unilateral Refusal to Licence Indispensable Intellectual Property Rights - US and EU Approaches', in J Drexl (ed), Research Handbook on Intellectual Property and Competition Law (Edward Elgar, Cheltenham 2008) 224-7. 
$\mathrm{EFD}^{17}$ because it refers to goods (or here: technology) that are used internally and not marketed externally.

Second, it was unclear whether the new product test is a prerequisite for compulsory licences in general. The test had already been mentioned in the Magill decision, but not as a cumulative prerequisite. Some commentators argued that the test is only an example of what might constitute abusive conduct in situations in which only one market exists. ${ }^{18}$ This is of high practical relevance because a strict application of the new product test would narrow the scope of application for compulsory licensing significantly. It would also lead to questions about the precise meaning of 'new', which could be interpreted as 'better', 'different', 'more comprehensive' or 'more affordable'. ${ }^{19}$ The conceptual basis and the exact prerequisites for compulsory licences remained unclear.

\subsubsection{Microsoft}

In 2007 the CFI determined another case on the abuse of IP rights. In 2004, the European Commission found that the Microsoft Corporation had abused its dominant position in the market for operating systems. ${ }^{20}$ It claimed that Microsoft had unlawfully refused to provide software protocols to its competitors which would have enabled them to interoperate with Microsoft products. ${ }^{21}$ The CFI confirmed the Commission's decision. The court held that the new product test cannot be the only parameter which determines whether a refusal to license is capable of causing prejudice to consumers within the meaning of Art 82 EC (now Art 102 TFEU). Such prejudice may arise where there is a limitation not only in respect of production or markets, but also in respect of technical development. Microsoft's refusal to provide the software protocols impeded the interoperability of operating systems and thus hampered technical development. That means the CFI applied a very wide understanding of the new product test, mitigating the strict IMS Health formula. However, it remained unclear whether it is possible to generalize the Microsoft decision because the decision was based on the intricacies of the new internet economy with its strong interdependencies and extremely dynamic markets. It is unclear whether it can be applied to all cases of abuse of market power and IP rights. The matter was never brought before the ECJ, leaving room for further doubts.

17. F Fine, 'NDC/IMS: A Logical Application of Essential Facilities Doctrine' (2002) 23 Europ Comp LR 457.

18. For example Leistner, supra (n 15), 150-51; Heinemann, supra (n 15), 72-5.

19. See also C Ahlborn, DS Evans and AJ Padilla, 'The Logic \& Limits of the "Exceptional Circumstances Test" in Magill and IMS Health' (2004) 28 Fordham Int LJ 1109, 1124; I Lianos, 'Competition Law and Intellectual Property Rights: Is the Property Rights' Approach Right?' (2005-2006) Cambridge Yearbook of European Legal Studies 153, 161-4.

20. European Commission, Commission Decision of 24 March 2004, Case COM/C-3/37.792 Microsoft.

21. Court First Instance, Judgment of 17 September 2007, Case T-201/04 - Microsoft v Commission. For discussion, see C Ahlborn and DS Evans, 'The Microsoft Judgment and its Implications for Competition Policy Towards Dominant Firms in Europe' (2008-2009) 75 Antitrust LJ 887. The Commission had also claimed that Microsoft had tied the Windows Media Player to its Windows operating system. This is a typical situation of tying which will not be discussed in more detail. 


\section{DEVELOPMENTS IN GERMANY - STANDARD SPUNDFASS AND ORANGE BOOK STANDARD}

\subsection{German courts as Europe's main patent litigation forum}

The importance of compulsory licences under German law transcends the national level because Germany is by far the most important forum for patent litigation in Europe. Practitioners and scholars estimate that between $1250^{22}$ and $1400^{23}$ out of 2000 infringement proceedings per year in Europe take place in German courts, which equates to about two-thirds ${ }^{24}$ of all patent litigation. ${ }^{25}$ One study even suggests that, depending on how cases are counted, the total caseload in Germany is between 12 and 29 times larger than in the UK. ${ }^{26}$

There are several reasons for this phenomenon. ${ }^{27}$ Patent litigation in Germany comes with relatively low costs ${ }^{28}$ which allows small and medium-sized companies to enforce their rights. ${ }^{29}$ German patent law does not give the judge discretion as to whether an injunction order is granted ${ }^{30}$ making the procedural situation favourable for plaintiffs. Litigation in Germany is said to be particularly efficient because the questions of infringement and validity of the patent are separated (bifurcation). ${ }^{31}$ A defendant claiming that the patent is invalid must file a separate invalidity action at the German Federal Patent Court (Bundespatentgericht). The court dealing with the infringement may wait for this ruling, but is under no obligation to do so, ${ }^{32}$ and such a stay of proceedings is handled very reluctantly in practice. ${ }^{33}$ In addition, German judges see it as their duty to take an active role in the proceedings, resulting in a streamlined process and a focus on the real issues of the case. This avoids unnecessary

22. Interview with Felicia Boyd about the Patent Trial and Appeal Board (17 October 2014), available at $<$ www.ipfridays.com $>$.

23. H Goddar and CR Haarmann, 'Patent Litigation in Germany - An Introduction', China Intellectual Property No. 1-2/2013, 68.

24. V Henke and R Böhm, 'Patent Litigation in Germany' (American Bar Association Intellectual Property Litigation Newsletter, Spring 2013), available at <www.americanbar.org $>$.

25. Apparently the gap between the different patent forums has widened over the last decade. A survey conducted by the Council of the European Union in 2007 suggested that German patent courts were dealing with about 600-700 matters p.a., while France (450 matters p.a.) and England (150 matters p.a.) appeared to be less popular, see Council of the European Union, Working Document 11622/07 (12 July 2007) 23-31.

26. K Cremers et al., 'Patent Litigation in Europe' (ZEW Discussion Paper No 13-072, 1 September 2013) 2; available at <http://ftp.zew.de/pub/zew-docs/dp/dp13072.pdf >.

27. For a good overview, see S Luginbuehl, European Patent Law - Towards a Uniform Interpretation (Edward Elgar, Cheltenham 2011) 39-41.

28. M Wirtz and R Liesegang, 'Patent Litigation in Germany', EPI Information No. 3/2003, 71,75 ; Henke and Böhm estimate that costs in Germany are typically only about a tenth of those incurred in similar cases before US courts, see Henke and Böhm, supra (n 24).

29. J Brinkhof, 'Die Schlichtung von Patentstreitigkeiten in Europa: Über Traum, Wirklichkeit und Vision' (2001) GRUR 600, 602.

30. See also below section 3.3.1.

31. P Meier-Beck, 'Damages for Patent Infringement According to German Law - Basic Principles, Assessment and Enforcement' (2004) 35 IIC 113, 114.

32. Meier-Beck, ibid.

33. Luginbuehl, supra (n 27), 40. 
delays and promotes a short duration of the proceedings. ${ }^{34}$ Moreover, the German decisions have a reputation for being of high quality because matters are confined to a small number of courts, resulting in a high level of expertise. ${ }^{35}$ The combination of these factors makes patent litigation in Germany interesting for foreign patent owners. Thomas Kühnen, Chief Justice at the Higher Regional Court of Düsseldorf, Germany's most important patent litigation forum, estimates that about 60 per cent of plaintiffs and defendants are non-German. ${ }^{36}$ It is therefore not surprising that German courts also became the primary forum for litigation of patents in industry standards. ${ }^{37}$

This peculiarity of the European patent litigation landscape is relevant for this article. German court practice is not just the practice in a singular EU member state, but the relevant court practice for the majority of patent litigation in Europe. Hence, it is not surprising that the main impetus for the Huawei./. ZTE decision came from the German patent infringement courts. This part of the article therefore discusses the developments of compulsory licensing in Germany, in particular the principles set out by the German Federal Court of Justice (FCJ) in its decisions Standard Spundfass and Orange Book Standard. ${ }^{38}$

\subsection{Standard Spundfass}

The first German landmark decision on compulsory licences was Standard Spundfass in 2004. ${ }^{39}$ The case in issue involved a standardized type of industry drum with a patented draining mechanism. As a result of a recommendation made by the Chemical Industry Association (VCI), this drum design became a de facto industry standard in Germany. The VCI had initiated an open competition for the best new industry standard, and the winner of the competition was under an obligation to grant free licences to other companies which had also submitted designs. Thus, the proprietor granted free licences to the other participants of the competition and non-gratuitous licences to all other market participants. A competitor then approached the proprietor and demanded a free licence on the basis that the proprietor had granted free licences to other companies. This demand was rejected by the FCJ because the proprietor had a justification for the different treatment. However, the court affirmed in principle an obligation to grant a licence if use of the protected technology is necessary for accessing downstream product markets where the patent is part of an established market standard.

34. J Pagenberg, 'The First Instance European Court - a Tribunal without Judges and Attorneys?' (2000) 31 IIC 481, 497. The average duration of proceedings is nine months in Germany, ten months in the Netherlands, 11 months in the UK and 24 months in France, see Cremers et al., supra (n 26), 4.

35. Meier-Beck, supra (n 31).

36. T Kühnen, Patent Litigation Proceedings in Germany (Wolters Kluwer/Heymanns, 7th edn, 2015), Foreword, v; similarly C Ann, 'Verletzungsgerichtsbarkeit - zentral für jedes Patentsystem und doch häufig unterschätzt' (2009) GRUR 205.

37. P Larouche and N Zingales, 'Injunctive Relief in Disputes Related to Standard-Essential Patents: Time for the CJEU to Set Fair and Reasonable Presumptions' (2014) 10 Eur Comp J 551, 564.

38. For a comprehensive overview of material patent law and patent litigation in Germany, see Kühnen, supra (n 36), passim.

39. Federal Court of Justice, File Number KZR 40/02, 13 July 2004, reported in BGHZ 160, 67 - Standard Spundfass. Reference will be made to the English translation available at (2005) 36 IIC 741. 
Although not expressly stated by the Court, it is widely accepted that the licence conditions need to be fair, reasonable and non-discriminatory. ${ }^{40}$

Despite covering different issues and setting out different prerequisites for the licence, the thrust of the FCJ decision is roughly consistent with the ECJ decisions Magill and IMS Health. Both courts used arguments which were developed under the EFD. ${ }^{41}$ Similar to IMS Health, the Standard Spundfass related to a de facto standard. ${ }^{42}$ However, the issue was not a unilateral refusal to licence, but alleged discriminatory conduct. In contrast to the ECJ, the FCJ did not mention any product requirements (cf the new product test), but merely referred to the barred access to downstream product markets as the main prerequisite. ${ }^{43}$

\subsection{Orange Book Standard ${ }^{44}$}

\subsubsection{Background and decision}

After Standard Spundfass, more and more defendants in patent infringement proceedings argued that the proprietor could not be granted injunction orders on the basis that the proprietor was under an obligation to license the patent (so-called 'Zwangslizenzeinwand', which could be translated as competition law defence). German patent law and competition law rules do not address this issue expressly. The courts therefore needed to apply general law principles to determine whether the competition law defence could be successfully raised, and what the prerequisites would be. Importantly, unlike common-law-based jurisdictions, German patent law does not provide the courts with discretion if a patent has been infringed. The last resort is the good faith doctrine under Sec 242 of the Civil Code, which can only be applied in cases in which the strict application of the law would have unbearable results. ${ }^{45}$ Even if the proprietor is under an obligation to grant the licence, the German legal framework makes it very difficult to restrain his or her rights because the patent is valid and no licensing agreement exists. ${ }^{46}$

40. For example, J Herr, 'Patent Litigation and Industry Standards: The Compulsory Licence Defence' (2009) 21 IP \& Tech LJ 10; P Treacy and S Lawrance, 'FRANDly Fire: Are Industry Standards Doing More Harm than Good?' (2008) 3 Journal of Intellectual Property Law \& Practice 22; L Zhang, 'How IPR Polices of Telecommunication Standard-Setting Organisations Can Effectively Address the Patent Ambush Problem' (2010) 41 IIC 380, 401.

41. KC Liu, 'Rationalising the Regime of Compulsory Patent Licensing by the Essential Facilities Doctrine' (2008) 39 IIC 757.

42. Nevertheless, subsequent court decisions are clear about the fact that the obligation to grant a licence as well as potential competition law defences apply to de facto and contractual market standards in the same manner, see, eg, Court of Appeal Düsseldorf, UMTS Mobilstation, File Number 4b O 273/10, 24 March 2011.

43. This simplified approach was praised as economically sounder than the new product rule as set out in IMS Health, see M Leistner, 'Standard Spundfass - Comment' (2005) 36 IIC 750.

44. For a detailed discussion of the decision, focusing on the intricacies of German law, see P Maume, 'Compulsory Licensing in Germany', in KC Liu and R Hilty (eds), Compulsory Licensing: Practical Experiences and Ways Forward (Springer, Heidelberg/New York/Dordrecht/London 2014) 99-116.

45. There is a vast body of literature on the methodology behind the application of $\S 242 \mathrm{BGB}$. The seminal treatise is F Wieacker, Zur rechtstheoretischen Präzisierung des § 242 BGB (Tübingen, 1956); for the most comprehensive overview, see D Looschelders and D Olzen in Staudinger, Kommentar zum Bürgerlichen Gesetzbuch (Sellier-de Gruyter, 2015) § 242, para 101-45.

46. Maume, supra (n 44), 105-8. For this reason equity-based tests can hardly be applied under German law. 
In May 2009, the FCJ published its decision Orange Book Standard. ${ }^{47}$ The Orange Book Standard is part of the 'Rainbow Books', a collection of compact disc specifications. The defendant argued that the proprietor was under an obligation to grant a licence under the Standard Spundfass principles, and raised the competition law defence against the proprietor's application for an injunction order. The FCJ stated that the competition law defence would be allowed on two conditions. First, the defendant must have made an offer under fair, reasonable and non-discriminatory conditions that the proprietor could not lawfully refuse. ${ }^{48}$ If the proprietor refuses to state appropriate conditions, or if these conditions seem unreasonable, the defendant is allowed to make an unspecified offer and to request the proprietor to determine the amount of royalties owed. ${ }^{49}$ The policy reason is that the information asymmetry between proprietor and defendant will usually make it extremely difficult for the defendant to find conditions which are appropriate. Second, the defendant must act according to the offer that he made, which means the defendant needs to pay or put the royalties that he had offered prior to using the patent into escrow. ${ }^{50}$ Here the reason is that the court does not want infringers to gain a competitive advantage over 'ordinary' users who obtained a licence prior to using the protected technology.

\subsubsection{Uncertainties and consequences ${ }^{51}$}

At first, the decision was welcomed by the majority of commentators, ${ }^{52}$ although some considered the new procedure critical under EU competition law. ${ }^{53}$ As time went by it became obvious that the Orange Book Standard principles were difficult to handle in practice. First, the FCJ required the potential licensee to make an unconditional offer for a licence agreement. The Regional Court Mannheim held in late 2011 that the potential licensee cannot make the offer under the condition that the patent is and remains valid, which means the user is not allowed to challenge the validity of the patent in separate proceedings. ${ }^{54}$ As a result, the user might be forced into a licence agreement although such an agreement is not necessary.

47. Federal Court of Justice, Orange Book Standard, File Number KZR 39/06, 6 May 2009, reported in BGHZ 180, 312. For convenience, reference will be made to the English translation available at (2010) 41 IIC 369.

48. Federal Court of Justice, ibid, para 29.

49. Ibid, para 40; see generally Kühnen, supra (n 36), 472-5.

50. Federal Court of Justice, ibid, para 36.

51. For more details, see Maume, supra (n 44), 109-12.

52. T Nägele and S Jacobs, 'Zwangslizenzen im Patentrecht' (2009) WRP 1062; J Busche, 'Der Einwand der Zwangslizenz im Patentverletzungsverfahren' (2009) CIPR 104; M Jestaedt, 'Der Lizenzerteilungsanspruch nach der BGH-Entscheidung Orange Book Standard' (2009) GRUR 801; A Gärtner and T Vormann, 'Der kartellrechtliche Zwangslizenzeinwand im Patentverletzungsstreit - Orange Book Standard und seine Folgen für die Praxis' (2009) Mitt 440.

53. H Ullrich, 'Patents and Standards - A Comment on the German Federal Supreme Court Decision Orange Book Standard' (2010) 41 IIC 337; GK de Bronett, 'Gemeinschaftsrechtliche Anmerkungen zum Orange-Book-Standard-Urteil des BGH' (2009) WuW 899.

54. Regional Court Mannheim, GPRS-Zwangslizenz, File Number 7 O 122/11, 9 December 2011, available at <http://openjur.de/u/357699.html>. Similarly, Court of Appeal Karlsruhe, GPRS-Zwangslizenz III, File Number 6 U 136/11, 13 June 2012, available at <http://openjur. de/u/357979.html>. 
Second, the territorial scope of the offer remained unclear. Is it sufficient that the user restrains his or her offer to the national (here: German) patent $?^{55}$ Or is the user under an obligation to request licences for other countries as well? A closely related question is whether the user may make an offer in respect of a licence for a single patent or whether the user needs to accept a pool licence, including other patents that the user may not require.

Third, the application of the escrow model raised questions. The Court held that if an amount has been deposited, which in any event is sufficient, the infringement court may limit itself to determining whether the proprietor is obliged to accept the offer of a licence contract. ${ }^{56}$ The wording suggests that an amount that is in any event sufficient' is higher than a 'reasonable' amount (which would be owed under FRAND conditions). The ongoing 'patent wars ${ }^{\prime}{ }^{57}$ and the series of contested patents might force users to deposit higher royalties or even unnecessary royalties in a number of cases simultaneously, putting a strain on the company's cash flows.

\subsubsection{Criticism $^{58}$}

Without a competition law defence, the proprietor's obligations under competition law would be rather useless in practice. The court's idea to keep the infringement proceedings free of complex deliberations about the correct amount of royalties is smart. The rationale to impose certain obligations on the user in order to keep the proprietor's financial interests safe also makes sense. Nevertheless, it is not surprising that the established criteria were difficult to handle in practice. As the FCJ relied on German legal principles only, courts in other EU countries have been reluctant to apply the Orange Book Standard principles. ${ }^{59}$

The FCJ draws a parallel between the defendant and a hypothetical licensee in a regular licence agreement. ${ }^{60}$ This is a dangerous deduction because the background of the Orange Book Standard model is a dominating undertaking which is abusing its market power. In this situation, the equality of bargaining powers which underlies all contractual theory is flawed. Using an honest licensee as an analogy misconceives the diversity of possible business situations and factually leads to a code of conduct that is set out by judges and not by market participants. It is doubtful that this outcome is desirable. The approach is unconvincing because an honest licensee might behave in various, unpredictable ways. Companies regularly enter into negotiations with offers that are not objectively reasonable. In the course of the negotiations they will come to a compromise that will usually be on reasonable terms. However, does the initial unreasonable offer make them dishonest licensors and licensees?

So despite the sound motives for the decision, the execution of the idea was problematic. The exact conditions on which the competition law defence could be raised remained unclear, resulting in proprietor-friendly legal uncertainty. Between 2009 and 2013, the defence was raised in hundreds of infringement cases, but only in two cases successfully. ${ }^{61}$

55. See also infra para 5.2.4.1.

56. Federal Court of Justice, supra (n 47), para 40.

57. For discussion, see A Jones, 'Standard Essential Patents: FRAND Commitments, Injunctions and the Smartphone Wars' (2014) 10 Europ Comp J 1.

58. For more details, see Maume, supra (n 44), 113-16.

59. See infra para 5.2.

60. Federal Court of Justice, supra (n 47), para 39.

61. A Verhauwen, 'The End of the "Golden Orange-Book Standard"' (2013) 8 JIPL\&P 879, 880. 


\subsection{Development in other EU member states}

Patent infringement courts in other EU member states also determined cases in respect of FRAND declarations and standards before 2013. ${ }^{62}$ In the UK, the High Court refused to grant an injunction order in $2012 .{ }^{63}$ In this case the plaintiff (IPCom) had given a FRAND declaration. The court considered an injunction inadequate since the defendant (Nokia) had agreed to accept a FRAND licence, subject to the terms decided by the court. In the Netherlands, the District Court The Hague expressly dismissed the Orange Book Standard approach in a comparable case in $2010 .^{64}$ The court argued that even if a FRAND declaration had been made, the existence of a mere entitlement to a compulsory licence could not prevent a proprietor from enforcing its rights. ${ }^{65} \mathrm{In}$ 2012, the same court accepted a FRAND defence, arguing that applying for an injunction was abusive if the parties were in negotiations. ${ }^{66}$ In France, the Paris Court of Appeal rejected the granting of a preliminary injunction order in late 2011 because it was seen as inappropriate. ${ }^{67}$ In 2012, the Court of Milan rejected a preliminary injunction order on similar grounds. ${ }^{68}$ As this brief overview demonstrates, patent litigation courts in other EU member states appeared to be less inclined to grant injunction orders than the German FCJ.

\section{STANDARDIZATION AND FRAND DECLARATION}

\subsection{Standardization under Art 101 and Art 102 TFEU}

Standardization is the process of developing, aligning and implementing technical standards. ${ }^{69}$ Standards can have great advantages for manufacturers and consumers, in particular regarding the compatibility of different devices. ${ }^{70}$ Without standards, devices would need to have a plethora of connectors, plugs and converters, increasing

62. For discussion of decisions on FRAND declarations in Asia, see LB Greenfield, H Schneider and J Mueller, 'SEP Enforcement Disputes Beyond the Water's Edge: A Survey of Recent Non-U.S. Decisions' (2013) 27 Antitrust 50, 53-4; for an overview of developments in the US, see M Fröhlich, 'The Smartphone Patent Wars Saga: Availability of Injunctive Relief for Standard Essential Patents' (2014) 9 JIPL\&P 156, 157.

63. Nokia v IPCom [2012] EWHC $1446(\mathrm{Ch})$. For more detailed discussion of the situation in the UK, see Larouche and Zingales, supra (n 37), 559-61.

64. District Court The Hague, Philips Electronics v SK Kassetten, File Number 316522/HA ZA 08-2522, 17 March 2010, para 6.19-6.25, available at <http://www.eplawpatentblog.com/ eplaw/2010/03/nl-philips-v-sk-kasetten-frand.html>.

65. Ibid, para 6.20 .

66. District Court The Hague, Samsung Electronics v Apple, joined cases 400367/HA ZA 11-2212, 400376/HA ZA 11-2213 and 400385/HA ZA 11-2215, 14 March 2012, available at <http://www.eplawpatentblog.com/eplaw/2012/03/nl-samsung-v-apple-frand.html $>$.

67. Tribunal de Grand Instance de Paris, 8 December 2011, available at $<$ http://www.foss patents.com/2011/12/french-court-denies-samsung-request-for.html>.

68. See Larouche and Zingales, supra (n 37), 561.

69. For a comprehensive overview of standardization in theory and practice, see C Tapia, Industrial Property Rights, Technical Standards and Licensing Practices (FRAND) in the Telecommunications Industry (Carl Heymanns/Wolters Kluwer, 2010) 11 et seqq.

70. The advantages of standardization in general are beyond question; see for example Recital 3 of Reg. 1025/2012 (relating to European Standardisation). A seminal treatise is MA Lemley, 'Intellectual Property Rights and Standard-Setting Organizations' (2002) 90 Cal LR 1889. 
cost and decreasing functionality. It is a logical consequence that manufacturers seek agreements on standards. These are typically negotiated under the auspices of standard-setting organizations (SSO), such as the Comité Européen des Normalisation (CEN) and the Comité Européen de Normalisation Electrotechnique (CENELEC). In the licensing context, arguably the most important European SSO is the European Telecommunications Standards Institute (ETSI).

Notwithstanding the benefits, standardization agreements are problematic under Art 101(1) TFEU (prohibition of anticompetitive conduct). The reason is that any agreement to standardize technology eliminates competition between alternative technologies. ${ }^{71}$ However, EU competition law also acknowledges that standards are necessary and, on balance, beneficial. The overarching condition set out by the European Commission in the "horizontal guidelines'72 is that these standards must remain open. ${ }^{73}$ Accordingly, SSOs must ensure effective access to the standards on fair, reasonable and non-discriminatory terms. ${ }^{74}$ This openness becomes a problem if a patent needs to be used to comply with a standard (standard essential patent, SEP). As a result, SSOs typically require their members to make a declaration that they will grant licences for their SEPs on FRAND conditions. ${ }^{75}$ The second problem of standardization agreements is that they automatically create a dominant market position for all owners of SEPs. Thus, according to the ECJ rulings Magill and IMS Health, SEP owners are under an obligation to grant licences under Art 102 TFEU.

\subsection{Implications}

A FRAND declaration can have impact on the obligation to grant a licence under Art 102 TFEU. A first line of thought focuses on the impact of standardization on competition. As standards usually contain numerous technologies, they often affect hundreds of SEPs held by a great number of owners. For example, more than 600 patents were declared essential for the MPEG2 standard and as many as 4000 patents for the UMTS standard. ${ }^{76}$ Theoretically, the holder of one single SEP can exclude everyone, including competitors, from using their patent - and thus the entire standard (so-called 'patent ambush' or 'patent holdup'). ${ }^{77}$ The standard would not be open any more. The mere threat of an injunction order can dramatically influence the negotiations

71. For detailed analysis of the implications for competition, see RP Merges and JM Kuhn,

'An Estoppel Doctrine for Patented Standards' (2009) 97 Cal LR 1, 7 et seqq.

72. European Commission, 'Guidelines on the Application of Article 101 of the Treaty on the Functioning of the European Union to Horizontal Co-operation Agreements', 14 January 2011, OJ C 11/01.

73. Ibid, para 268.

74. Ibid, para 283.

75. See the famous ETSI IPR Policy Clause 6.1, available at <http://www.etsi.org/images/files/ ipr/etsi-ipr-policy.pdf>.

76. See Tapia, supra (n 69), 41-2. It has to be noted that there is a tendency towards overdeclaration in the market, see DL Martin and C De Meyer, 'Patent Counting, a Misleading Index of Patent Value: A Critique of Goodman \& Myers and its Uses' (Working Paper, 4 December 2006), available at SSRN.

77. For extensive discussion of patent holdups, see TF Cotter, 'Patent Holdup, Patent Remedies, and Antitrust Responses' (2008-2009) J Corp L 1151, 1160-71; MA Lemley and C Shapiro, 'Patent Holdup and Royalty Stacking' (2007) 85 Texas LR 1991. 
between the SEP holder and an alleged infringer. ${ }^{78}$ A consequence could be that SEP holders could not apply for injunction orders. ${ }^{79}$

By holding a patent which is upgraded to an SEP, the proprietor will be particularly well remunerated. The policy reason for patent protection is that the investor needs to disclose the invention to the general public. This disclosure allows the inventor to reap the rewards of exclusivity. The concept does not encompass the rewards of having an SEP, which also reward the popularity of the established market standard. From an economic perspective, the proprietor is overcompensated. ${ }^{80}$

A third line of thought focuses on the FRAND declaration itself. The proprietor who makes a FRAND declaration could be held accountable for the declaration. For example, it could be seen as a general commitment which could be taken into account by national courts, for instance in the court's discretion as to whether to grant an injunction or as an abusive exercise of rights under the good faith doctrine. ${ }^{81}$ Nevertheless, German courts were reluctant to take these arguments into account. The Regional Court Mannheim repeatedly held that FRAND declarations are not legally binding because they lack finality of terms and intention to enter into the contract. ${ }^{82}$ The court also held that according to the principle of national protection, the case was to be resolved under German law. As a result, the fact that a proprietor gave a FRAND declaration could not be used as a defence in German courts. Reading through the Regional Court Mannheim decision, it appears that the court went out of its way to make sure that the matter was decided under German IP law only.

\subsection{The Samsung and Motorola investigations}

In January 2012 the European Commission opened an investigation against Samsung Electronics. ${ }^{83}$ It had the suspicion that Samsung had not honoured its FRAND declaration given to ETSI in 1998. In December 2012, the Commission sent a Statement of Objections to Samsung, claiming that the company abused its market power by applying for an injunction order. ${ }^{84}$ The prerequisite of this abuse

78. For example, Lemley and Shapiro, ibid, 1994 et seqq; and against that, JG Sidak, 'Holdup, Royalty Stacking, and the Presumption of Injunctive Relief for Patent Infringement: A Reply to Lemley and Shapiro' (2008) 92 Minn LR 714.

79. Lemley and Shapiro, supra (n 77); Merges and Kuhn, supra (n 71). Naturally, the views of stakeholders strongly diverge on this issue, see Fröhlich, supra (n 62).

80. Merges and Kuhn, supra (n 71); J Farrell, J Hayes, C Shapiro and T Sullivan, 'Standard Setting, Patents, and Hold-Up' (2007) 74 Antitrust LJ 603, 610-15.

81. The problem is the implementation of this approach into the national legal frameworks. For an overview of the debate under German law see Tapia, supra (n 69), 18-32.

82. Most importantly, Regional Court Mannheim, FRAND-Erklärung, File Number 7 O 94/08, 27 February 2009. The Higher Regional Court Karlsruhe confirmed this approach, see Higher Regional Court Karlsruhe, FRAND-Grundsätze, File Number 6 U 66/09, 23 March 2011.

83. European Commission, 'Antitrust: Commission Opens Proceedings Against Samsung' (Press Release IP 12/89, 31 January 2012), available at <http://europa.eu/rapid/press-release_IP-12-89_en. $\mathrm{htm}>$. For discussion, see Verhauwen, supra (n 61), 882-4. The first important investigation (Rambus) will not be discussed in more detail here. For discussion, see Tapia, supra (n 69), 111-26; D Culley, M Dhanani and M Dolmans, 'Learning from Rambus - How to Tame Those Troublesome Trolls' (2012) 57 Antitrust Bulletin 117; Farrell et al., supra (n 80), 605-7.

84. European Commission, 'Antitrust: Commission Sends Statement of Objections to Samsung on Potential Misuse of Mobile Phone Standard-Essential Patents' (Press Release IP/12/ 1448, 21 December 2012), available at <http://europa.eu/rapid/press-release_IP-12-1448_en.htm? locale $=\mathrm{FR}>$. 
is that the patent user is willing to enter into a licence agreement with the SEP holder on FRAND terms ('willing licensee' concept). The Commission also pointed out that it stayed in close contact with US competition authorities (Department of Justice and Federal Trade Commission) on issues relating to SEP patents, ${ }^{85}$ making it clear that the Commission's opinion was not isolated. ${ }^{86}$ Subsequently, Samsung addressed the Commission's concerns by declaring that they would not file a claim seeking injunctive relief against potential licensees that agreed to an invitation to negotiate offered by Samsung. On 29 April 2014 the Commission accepted these commitments and declared them legally binding under Art 9 of Regulation 1/2003 ('commitment decision'), ending the investigation. ${ }^{87}$

In April 2012 the Commission opened an investigation against Motorola Inc. A Statement of Objections was sent in May 2013, mirroring the allegations that were made against Samsung. ${ }^{88}$ The Commission expressly voiced concerns about the application of the Orange Book Standard rules by German courts. The Commission argued that a rule whereby a willing licensee is effectively not entitled to challenge the validity and essentiality of the SEPs in question ${ }^{89}$ is potentially anticompetitive. ${ }^{90}$ On 29 April 2014 the Commission published its decision, stating that Motorola had breached Art 102 TFEU by seeking and enforcing an injunction against its competitor, ${ }^{91}$ although the competitor had made no less than six offers to enter into a licence agreement on FRAND terms. ${ }^{92}$ These decisions made it clear that the Commission took a different and more user-friendly approach than the German courts. Under the Commission's approach, it is the holder of an SEP who must approach the user and make a formal invitation to negotiate, requiring him to be proactive. ${ }^{93}$ This lenient "willing licensee' approach - although making perfect sense from a competition law angle could open the door for delaying tactics, potentially transforming the enforcement of SEPs into an uphill battle.

85. European Commission, 'Samsung - Enforcement of ETSI Standards Essential Patents (SEPs) - Questions and Answers' (Memo IP 12/1021, 21 December 2012), available at $<$ http://europa.eu/rapid/press-release_MEMO-12-1021_en.htm>.

86. Verhauwen, supra (n 61), 884.

87. European Commission, Summary Decision of 29 April 2014, Case AT.39939 - Samsung, OJ 350/8, 4 December 2014.

88. European Commission, 'Antitrust: Commission Sends Statement of Objections to Motorola Mobility on Potential Misuse of Mobile Phone Standard-Essential Patents' (Press Release IP 13/406, 6 May 2013), available at <http://europa.eu/rapid/press-release_IP-13-406_en.htm>.

89. This was the view of the Regional Court Mannheim and the Higher Regional Court Karlsruhe; see supra section 3.3.2 of this article.

90. European Commission, 'Antitrust: Commission Sends Statement of Objections to Motorola Mobility on Potential Misuse of Mobile Phone Standard-Essential Patents - Questions and Answers' (Memo IP 13/403, 6 May 2013), available at <http://europa.eu/rapid/press-release_ MEMO-13-403_en.htm>.

91. European Commission, Summary Decision of 29 April 2014, Case AT.39985 - Motorola, OJ 344/6, 2 December 2014.

92. European Commission, Commission Decision of 29 April 2014, Case AT.39985 (Public Version), available at <http://ec.europa.eu/competition/antitrust/cases/dec_docs/39985/ 39985_928_16.pdf>.

93. Larouche and Zingales, supra (n 37), 569. 


\section{THE CENTRE STAGE - HUAWEI ./. ZTE}

\subsection{The referral by the Regional Court Düsseldorf}

The Commission's approach had a direct impact on court proceedings in Germany. Under Art 16(1) of Reg. (EC) 1/2003 national courts must ensure the uniform application of EU competition law. If a decision is contemplated by the Commission (for example, after opening an investigation but before publishing the final decision), the national court may assess whether it is necessary to stay its proceedings. If the national court is of the opinion that the Commission decision is not complying with EU competition law, it can refer the matter under Art 267 TFEU to the CJEU for a preliminary ruling.

In March 2013 a case about a standard in the telecommunications industry was brought before the Regional Court Düsseldorf. ${ }^{94}$ The patent in issue was part of the Long Term Evolution (LTE) Standard. It had been established under the auspices of ETSI and the proprietor had declared its willingness to grant FRAND licences. The proprietor and the user had been in negotiations between November 2010 and March 2011, but did not exchange formal offers for licence agreements. The Regional Court posed the question to the CJEU of what constitutes an abuse of a dominant undertaking in relation to an SEP, expressly related to the approaches taken by the German FCJ and the European Commission. The underlying question is whether the German model overburdens users, thereby limiting the effectiveness of EU law. ${ }^{95}$ The Regional Court argued that some conditions set out by the FCJ for an effective competition law defence under the Orange Book Standard do not appear to be compelling. It expressly referred to the Commission's press release in the Samsung investigation of 21 December 2012. The court expressed unease about the implications of the user's obligation to make an unconditional offer, which includes the prohibition of challenging the validity of the patent in court. ${ }^{96}$ The implication would be that SEPs would never be challenged. The Court argued that it is not in the public interest to maintain a patent if it was granted unlawfully. ${ }^{97}$

\subsection{The CJEU decision ${ }^{98}$}

On 16 July 2015, the CJEU handed down its decision Huawei ./. ZTE. The court essentially followed Advocate General Wathelet's opinion given in the hearing on 20 November $2014 .{ }^{99}$ In simple terms, the court followed the 'willing licensee' concept in principle, but introduced a new negotiation procedure. The Orange Book Standard principles must now be considered inapplicable if the proprietor gave a FRAND declaration.

94. Regional Court Düsseldorf, LTE-Standard, File Number 4b O 104/12, 21 March 2013.

95. This was one of the critical points of the Orange Book Standard decision; see de Bronett, supra (n 53).

96. The Regional Court Düsseldorf, supra (n 94), at 200.

97. Ibid.

98. Court of Justice of the European Union, Case C-170/13, 16 July 2015 - Huawei Technologies Co. Ltd v ZTE Corp.

99. Court of Justice of the European Union, Press Release No 155/14, 20 November 2014, available at $<$ www.curia.europa.eu $>$. 


\subsubsection{Injunctions and the abuse of rights}

The CJEU reiterated that the exercise of IP rights might be abusive in exceptional circumstances. ${ }^{100}$ In the eyes of the court, the first main feature distinguishing SEPs from regular patents is that SEPs are indispensable to all competitors which envisage manufacturing products that comply with the standard. ${ }^{101}$ The second main feature is the fact that the SEP proprietor gave an irrevocable undertaking that it is prepared to grant licences on FRAND terms. ${ }^{102}$ The FRAND declaration creates legitimate expectations on the part of prospective users that the proprietor will in fact grant licences on such terms. ${ }^{103}$ A refusal to grant such a licence can (in principle and taking into account the specific legal and factual circumstances of the case $)^{104}$ constitute an abuse within the meaning of Article 102 TFEU. ${ }^{105}$ As a result, the proprietor of an SEP cannot bring an action for an injunction or for the recall of products, even if the product has already been used by the infringer. ${ }^{106}$

\subsubsection{Reversing the table - the negotiation procedure}

The CJEU also set out a procedure for balancing the interests of the proprietor and the user. This is sound because one of the lessons of the German patent infringement cases is that many SEP infringers, as Verhauwen put it, do not sincerely intend to follow up their apparent willingness to negotiate. ${ }^{107}$ According to the CJEU, the proprietor needs to take the first step and alert the alleged infringer by designating the SEP and the way it has been infringed. ${ }^{108}$ If the user expresses its willingness to conclude a licensing agreement on FRAND terms, it is for the proprietor to present a specific written offer, specifying in particular the amount of the royalties and the way in which they are calculated. ${ }^{109}$ The user needs to reply diligently, in accordance with recognized commercial practices and in good faith (both to be established on objective factors), which in particular implies the absence of delaying tactics. ${ }^{110}$ If the user does not agree to the terms of this offer, they need to make a counter-offer on FRAND terms; otherwise the proprietor would be free to initiate patent infringement proceedings. ${ }^{111}$ If the counter-offer is rejected, it is for the user to provide appropriate security in accordance with recognized commercial practices (for example, bank guarantees). This includes a calculation for the security based on the number of uses of the SEP. ${ }^{112}$ If the parties do not come to an agreement on the details of the FRAND terms, the parties may, by common agreement, request that the amount of the royalty be determined without delay by an independent third party. ${ }^{113}$ The CJEU felt

100. CJEU, supra (n 98), 45-7.

101. Ibid, paras 49-50.

102. Ibid, para 51.

103. Ibid, paras 53-4.

104. Ibid, para 56.

105. Ibid, para 53.

106. Ibid, para 60.

107. Verhauwen, supra (n 61), 880.

108. CJEU, supra (n 98), para 61.

109. Ibid, para 63.

110. Ibid, para 65.

111. Ibid, para 66.

112. Ibid, para 67.

113. Ibid, para 68. 
compelled to point out that the user is still allowed to challenge the validity or the essentiality of the patent, even during the negotiations. ${ }^{114}$

The CJEU's arguments have a different trajectory than the FCJ in the Orange Book Standard decision. The German court had the rights of the proprietor in mind and discussed under what circumstances the user could raise the competition law defence, thus avoiding an injunction order. In contrast, the CJEU focuses on the thought that the proprietor who made a FRAND declaration will abuse its market power if it attempts to enforce the patent. This resembles the Commission's approach in the Samsung and Motorola investigations. ${ }^{115}$ This shift in perspective is reflected in the new negotiation procedure. It is the proprietor who needs to make the first move by notifying the alleged infringer. This might appear odd because it is the user who sets the procedure in motion by using the protected technology, but the approach is straightforward. The use of a patent that is really essential (ie, not subject to overdeclaration) is easy to detect because every product in the respective field needs to comply with the standard. Hence, from the proprietor's point of view, the market is transparent. Conversely, this is not the case from the user's point of view. Given the sheer number of SEPs and the problem of over-declaration, it is not certain that the user of one of those SEPs will necessarily be aware that they are using the teaching of an SEP that is both valid and essential to a standard. ${ }^{116}$ Thus, forcing the proprietor to take the first step is sound.

The same applies to the requirement that the proprietor needs to make a specified written offer on FRAND conditions. ${ }^{117}$ Specifying royalties has always been the trickiest part of licence negotiations. The proprietor of the SEP is better placed to check whether its offer complies with the condition of non-discrimination than the alleged infringer. ${ }^{118}$ Given the information asymmetry between proprietor and user, the user would have to make a guess about the appropriate royalties, hoping for the best. If the guess is too high, the proprietor will accept the offer, forcing the user into an unfavourable licence agreement. If the guess is too low, the proprietor can dismiss the offer as inappropriate and initiate infringement proceedings. The model chosen by the CJEU reverses the roles, placing the user in a position in which he can assess the proprietor's offer.

The CJEU is unable to prescribe the negotiation procedure in every detail. Instead, the court resorts to general terms such as 'recognized commercial practices in the field and good faith'. ${ }^{119}$ This provides national courts with leeway to be flexible in different fact settings, negotiation processes and business cultures. The question will be when the threshold for 'delaying tactics' is crossed.

\subsubsection{Essential facilities revisited?}

On the one hand, the new ECJ decision is a straight continuation of IMS Health in which the ECJ held that it might constitute an abuse of market power if an IP right is used to block the access to a downstream market. ${ }^{120}$ In the case of Huawei ./. ZTE,

114. Ibid, para 69.

115. See supra section 4.3 .

116. Opinion of AG Wathelet, Case No C-170/13, 20 November 2014, para 81.

117. CJEU, supra (n 98), para 63.

118. Ibid, para 64.

119. Ibid, para 65 .

120. ECJ, supra (n 14), paras 42-6. 
the SEP is the bottleneck (or in more formal terms: the essential facility) and the resulting product using the protected technology is the downstream market. In contrast to IMS Health, the CJEU did not mention the new product requirement. This is straightforward because the SEP holder typically does not use the IP merely internally (unilateral refusal-to-license, cf IMS Health), but is licensing it to third parties. Thus, the new decision should not be considered a typical application of the EFD, but a refusal-to-deal discrimination case. Not applying the new product requirement is sound because the user of the SEP is offering a product (most likely a smartphone) anyway. The refusal to grant a licence would eliminate a product from the market, causing detriment to consumers within the meaning of Art 102 TFEU.

The obligation to grant a licence should be distinguished from the new negotiation procedure as discussed above. The wording (in particular paras 53-4 which relate to 'legitimate expectations' of the user) suggests that the foundation of the new negotiation procedure is not the indispensability of the SEP, but the FRAND declaration. This leads to two conclusions. First, the obligation to grant a licence in order to avoid an abuse of market power is founded in the indispensability of the IP right. The obligation applies to all established standards, whether de facto or based on a standardization agreement. Second, as the legitimate expectations are primarily caused by the FRAND declaration, the application of the negotiation procedure is limited to cases in which a FRAND declaration has been made. This does not include de facto standards.

\subsubsection{Remaining questions}

5.2.4.1 Scope of the licence offer Another issue is the scope of the licence offer. Can the user require the proprietor to make a tailored offer, containing only the SEP in issue, or is the proprietor allowed to offer a typical pool licence? This issue was discussed in German courts several times. The District Court Düsseldorf held that the user does not have the right to claim a pool licence tailored to the user's particular needs. Instead, the Court found it acceptable for the user to accept a worldwide pool licence that was offered by the patentee. ${ }^{121}$ The Court of Appeal Düsseldorf left the question unanswered. ${ }^{122}$ The District Court Mannheim held that the user was not required to make an offer for a worldwide pool licence. ${ }^{123}$ This would only be the case if it could be expected that the user would infringe upon other patents held by the patentee. In the UK, the matter has been considered in two recent cases. In January 2015, the High Court held that a defendant is not necessarily 'forced to take a global portfolio licence in order to stave off a national injunction on that one patent'. ${ }^{124}$ Three months later the High Court asserted that a portfolio offer of all SEPs held by a patentee is capable of being FRAND. ${ }^{125}$ However, Birss J considered the matter as too complicated for summary determination and stated that although competition law considerations and the wider context might actually work in favour of an individual licence offer, the matter should be decided at trial. ${ }^{126}$

121. The District Court Düsseldorf, Videosignalcodierung III, File Number 4b O 78/07, 11 September 2008.

122. The Court of Appeal Düsseldorf, Interframe Dropping, File Number 2 U 131/08, 28 January 2010.

123. The District Court Mannheim, File Number 7 O 65/10, 27 May 2011.

124. Vringo v ZTE [2015] EWHC 214 (Pat), para 108.

125. Unwired v Huawei [2015] EWHC 1029 (Pat), para 37.

126. Unwired v Huawei [2015] EWHC 1029 (Pat), para 43. 
The solution is in the requirement to offer 'non-discriminatory' terms. The proprietor does not need to treat the user better than other licensees. If the proprietor usually offers the respective licence through an international licence pool, which was accepted by Birss $J$ in the decision Vringo $v$ ZTE as the international standard, ${ }^{127}$ then he is allowed to offer exactly the same conditions to the user. Forcing the proprietor to make a tailored offer that is different from the typical licence conditions would not be non-discriminatory, but a special treatment, which cannot be required under FRAND terms. The burden of proof for the non-discrimination would rest with the proprietor.

5.2.4.2 FRAND commitment and transfer of patent The question remains what happens if the proprietor makes a FRAND declaration and later transfers the patent to a third party. This issue had been considered by the District Court Mannheim in 2009. It was the court's view that the FRAND declaration which had been made by the old proprietor could not be binding for the new proprietor. As discussed above, ${ }^{128}$ the court focused on German contract law and patent law and did not take into consideration the competition law aspects of the case. The opposing view is that FRAND declarations, although given to ETSI, are enforceable by third parties because they are governed by French contract law. ${ }^{129}$ The European Commission stressed the positive effects of FRAND commitments on competition law and argued that when SEPs 'are transferred from one owner to another, so should any relevant FRAND commitments'. ${ }^{130}$ This suggests that an omission of the new owner to make such a declaration could be a breach of competition law in itself. ${ }^{131}$

In this respect, the wording of the Huawei ./. ZTE decision is unclear. In para 53, the court states that ' $\ldots$ an undertaking to grant licences on FRAND terms creates legitimate expectations on the part of third parties that the proprietor of the SEP will in fact grant licences on such terms ...'. This could be interpreted as legitimate expectations that 'a licence' would be granted, or that a licence would be granted 'by the current proprietor'. A valid argument would be that the addressee of the FRAND declaration is the SSO and not the user, thus linking the SEP to the standard and not to the company which made the declaration. That means that the new negotiation procedure requires a FRAND declaration in relation to the SEP, regardless whether by the old or the new proprietor.

\subsection{Harmonization of national patent infringement proceedings}

National IP laws are subject to a high level of international harmonization. Treaties such as the Agreement on Trade-Related Aspects of Intellectual Property Rights

127. Vringo v ZTE [2015] EWHC 214 (Pat), para 108.

128. See supra section 4.2 .

129. Robin Jacob, 'FRAND: A Legal Analysis' (Paper presented at the Euripides International Experts Workshop, Seville, 27 October 2014), available at <http://is.jrc.ec.europa.eu>; see also J Straus, 'Das Regime des European Telecommunications Standards Institute' (2011) GRUR Int 469 .

130. European Commission, 'Commission Welcomes IPCom's Public FRAND Declaration' (Press Release MEMO 09/549, 10 December 2009, available at <http://europa.eu/rapid/ press-release_MEMO-09-549_en.htm>.

131. In the respective case IPCom had, after long negotiations with the Commission, agreed to make a public FRAND declaration. 
(TRIPS) set out the minimum requirements for IP protection. Several uniform EU IP regimes ${ }^{132}$ and several European Directives on IP were created, further harmonizing national IP regimes. ${ }^{133}$ This does not only relate to the scope of IP rights, but also to some aspects of their enforcement. ${ }^{134}$ But despite this high level of harmonization, enforcement remains mostly national law, embedded in the rules of contract law and civil procedure. One implication of this embedment is that national patent litigation courts need to take into account the particularities of the different national legal frameworks. This is exactly what happened in the German decision Orange Book Standard. Courts in the UK, France, Italy and the Netherlands came up with their own approaches to address the issue of FRAND licensing and competition law defences. ${ }^{135}$

The CJEU is not bound by national particularities. The court's task is the interpretation of EU law, in this case the ambit of Art 102 TFEU. By setting out a procedure that accommodates the particularities of standardization in light of EU competition law, the CJEU de facto prescribed a harmonized procedure for patent litigation of SEPs in Europe. ${ }^{136}$ This harmonization is not thorough because terms like 'recognized commercial practices in the field and good faith' will need to be fleshed out by national courts. Different approaches will be taken, and further referrals to the CJEU will ensue. However, this is a great step for the harmonization of European patent law. A highly relevant question will be if the proprietor can initiate a compensation suit while negotiating with the user. If the negotiations fail, the proprietor could extend the ambit of the suit to include an application for an injunction order, speeding up the proceedings for an injunction order significantly. ${ }^{137}$

\section{SUMMARY AND OUTLOOK}

The decision Huawei ./. ZTE is a milestone. After years of legal uncertainty in the booming field of telecommunication it clarifies the scope of compulsory licensing. The obligation to grant a licence on FRAND terms covers both consensual and de facto standards, which is in line with the German decision Standard Spundfass. The new negotiation procedure builds upon the European Commission's idea of the SEP holder taking the initiative in the negotiation process. The procedure is balanced and not unduly in favour of prospective users. Importantly, it addresses the perennial problem of information asymmetries between user and proprietor. Since it is founded in the FRAND declaration, it does not apply to de facto standards. To this extent, the Orange Book Standard principles remain in place. The remarkable side-effect is that the CJEU aligned patent litigation of SEPs, and in one of the most important business sectors - the IT and telecommunications industry. The strong focus on common principles - instead of national legal particularities - also opens the door for comparative research in the near future.

132. For example, the Community trade mark (Reg. (EC) 207/2009, 26 February 2009, OJ L 78/1) and the Community design (Reg. (EC) 6/2002, 12 December 2001, OJ L 3/1).

133. For example, Directive 2001/29/EC on the harmonisation of certain aspects of copyright and related rights in the information society, 22 May 2001, OJ L 167/10.

134. See the Directive $2004 / 48 / C$ on the enforcement of intellectual property rights, 29 April 2004, OJ L 157/45.

135. For discussion, see Greenfield et al., supra (n 62).

136. This was already pointed out by Larouche and Zingales in respect of the European Commission's 'willing licensee' concept, see Larouche and Zingales, supra (n 37), 578.

137. Under the German rules of civil procedure this would be a viable option. 